\title{
Danish law to be less rigid
}

\section{Copenhagen}

Denmark's Minister of Environment is poised to allow the country's first deliberate releases of genetically modified organisms. Following a parliamentary debate on proposed field trials of sugar beet containing either a herbicide-resistant or a virus-resistant gene, Ms Lone Dybkjaer has indicated that she will grant the approvals that are necessary under the Environment and Gene Technology Act, Europe's only specific legislation for gene experiments. That decision is the latest sign that Denmark's three-year-old law is not necessarily as restrictive in practice as it seems on paper.

Among those most relieved by these signs are three large Danish companies with an interest in exploiting gene technology - Danisco, Novo-Nordisk and Carlsberg. Their criticisms of the law are only somewhat tempered by the increasing speed with which National Food Agency civil servants are dealing with applications, and by some amendments to the law that will come into force on $1 \mathrm{July}$.

For Novo-Nordisk, the pharmaceutical and enzyme company formed by a recent merger, the most important amendment to the 1986 law is the one that will allow pilot plants to be treated as research rather than production facilities and so be subject to less stringent regulations. A second relaxation means that a company

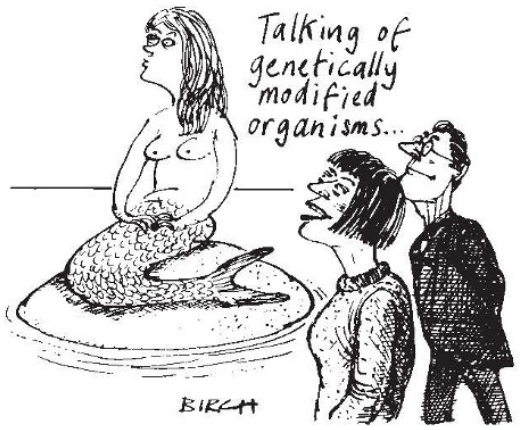

no longer has automatically to stop work when a complaint is lodged with the Environmental Appeal Board.

What has not changed, Novo-Nordisk complains, is the amount of time and paperwork involved in filing an application. Nor has there been any move towards substituting a procedure of notification for one of authorization for those organisms that are widely held to offer very little risk. Even so, as the world's largest supplier of industrial enzymes, Novo-Nordisk plans to be using gene technology to make all twenty or so enzymes that it sells within five years.

Danisco, the food conglomerate that is to field test the genetically modified sugar beet, is also keen to extend the application of gene technology. The company's director of biochemistry, Leif Kjaegaard, says that approval will be sought next year for follow-up field tests in Denmark, as well as for related trials in France and Britain. Meanwhile company scientists are working hard on other genetic modifications of both sugar beet and rapeseed.

The two genetically modified sugar beets to be field tested in Denmark next year will be the first using a commercially relevant line, Kjaegaard claims. One modification makes beet resistant to glyphosate, the active ingredient of Monsanto's herbicide Roundup, which is considered to be more environmentfriendly than most alternatives but is toxic to ordinary sugar beet. The other modification is designed to confer resistance to rhizomania, a disease caused by the beet necrotic yellow vein virus.

Although scientists at the Carlsberg Laboratory have hopes of genetically modifying the barley and yeast used in the breweries whose profits fund their research through the Carlsberg Foundation, they are not about to follow in Danisco's footsteps. One reason, says Diter von Wettstein, head of physiology, is the feeling that the public is not yet prepared to buy beer brewed with the aid of gene technology. Another is that the techniques for inserting new genes into barley are not yet perfected.

By the time they have been, Denmark's gene law may have been further relaxed. It is due for additional amendments in $1990 / 91$. One possibility is that it will at that stage fall into line with European Community regulations. Current Danish law is still considerably more restrictive on the contained use of genetically modified organisms than what seems likely to become the minimum European law (see below).

As for deliberate release, Europe is still in disarray, with current Danish law and German intentions appearing to be the most restrictive.

\section{ENGINEERERED ORGANISMS}

\section{Euro guidelines take shape}

\section{Munich}

European Community (EC) environment ministers on 8 June agreed on guidelines for the use of genetically modified organisms in laboratories or production facilities, but disagreed on how to regulate their release into the environment.

The guidelines were proposed last year by the European Commission, the executive body of the EC, and later amended by the European Parliament (see Nature 339, 413; 8 June 1989). The meeting of the Council of Environment Ministers was a first response to the amendments suggested by the Parliament, which will hold a second reading of the proposal this autumn. The council has the final say on the content of the proposal.

The council, meeting in Luxembourg, adopted some of the stricter guidelines proposed by the European Parliament on the use of genetically modified organisms in laboratories and production facilities. Under the guidelines adopted, "dangerous" modified organisms must be licensed by national authorities the first time they are used in a laboratory and every time they are used for production. In addition, the council recommended flexible deadlines for licensing procedures in order to allow for public participation.

The final proposal reflects West German wishes for stricter regulation, which France and Britain have traditionally opposed. The ministers disagreed about whether to require community-wide licensing of products containing modified organisms and intended for release. The minister from Spain, which holds the EC presidency until next month, decided after a brief discussion to return the proposal to a ministerial committee for further debate.

Regulations approved by the council comprise a minimum standard for EC member states, which are bound to adopt them. Member states are free to add to community regulations. Steven Dickman

EUROPEAN COMMISSION

\section{A new Framework is}

\section{established}

\section{Paris}

TEN joint research programmes were approved by European Community research ministers last week at a meeting of the Council of the European Commission in Luxembourg, and three others were passed for a second reading in the European Parliament. Ninety-one per cent (Ecu 482 million, about US\$530 million) of the EC Framework programme for research and technological development has now been committed, and a further 5 per cent earmarked for the three programmes still to receive final ratification.

The programmes include specific efforts on coastline protection, expert systems and automated language translation, as well as general projects to assess the purpose and effectiveness of research policy and technology development in the EC.

Research ministers also heard preliminary details of a proposal to streamline the EC's five-year plan which would make it a more flexible, rolling programme. Full details are expected in mid-July.

Peter Coles 